\title{
A NEW SPECIES OF SPHENACANTHID (CHONDRICHTHYES, ELASMOBRANCHII) FROM THE RIO DO RASTO FORMATION (PARANÁ BASIN), SOUTHERN BRAZIL
}

\author{
VICTOR EDUARDO PAULIV \\ Programa de Pós-Graduação em Geociências, Instituto de Geociências, UFRGS, Campus do Vale, \\ 91501-970, Cx.P. 15001, Porto Alegre, RS, Brasil.vpauliv@gmail.com \\ ELISEU VIEIRA DIAS
}

Laboratório de Geologia e Paleontologia, Centro de Ciências Biológicas e da Saúde, UNIOESTE, Rua Universitária 2069, 85819-110, Cascavel, PR, Brasil.eliseu.dias@unioeste.br

FERNANDO ANTONIO SEDOR

Museu de Ciências Naturais, Setor de Ciências Biológicas, UFPR, Centro Politécnico, Jardim das Américas, 81531-990, Cx.P. 19031, Curitiba, PR, Brasil.sedor@ufpr.br

\begin{abstract}
The chondrichthyan skeletal structures with the greatest potential for fossilization are teeth, scales, fin and cephalic spines. In the Rio do Rasto Formation, the Chondrichthyes are represented by finspines and teeth attributed to sphenacanthids, hybodontids and xenacanthids. Herein is presented new finspines collected from an outcrop of the Serrinha Member of the Rio do Rasto Formation, in the Municipality of Jacarezinho, Paraná State. The studied material consists of two finspines that are gradually tapered distally, with convex anterior and lateral faces. The posterior proximal face is strongly concave forming a furrow; absence of pronounced median ridge in the posterior distal face; the lateral faces have non-pectinated ribs separated by intercostal grooves, some of them bifurcated and beaded with rows of rounded closely spaced tubercles are the features that allow the finspines to be ascribed to a new species of Sphenacanthidae.
\end{abstract}

Key words: Permian, Guadalupian, Paraná Basin, Sphenacanthidae, finspines.

RESUMO - As estruturas com maior possibilidade de fossilização do esqueleto dos Chondrichthyes são aquelas mais mineralizadas, tais como dentes, escamas, espinhos cefálicos e de nadadeiras. Na Formação Rio do Rasto, os Chondrichthyes estão representados predominantemente por dentes e espinhos de nadadeiras e dentes atribuídos a esfenacantídeos, hibodontídeos e xenacantídeos. Aqui são apresentados novos espécimes de espinhos coletados em um afloramento do Membro Serrinha da Formação Rio do Rasto no Município de Jacarezinho, Estado do Paraná. O material corresponde a dois espinhos de nadadeiras, que gradualmente se reduzem distalmente, com as faces, anterior e lateral, convexas. A face proximal fortemente côncava formando um sulco; face distal posterior não apresentando crista mediana pronunciada, faces laterais com costelas não pectinadas, separadas por sulcos intercostais, sendo algumas delas bifurcadas, com tubérculos pequenos e pouco espaçados são as características que permitem que os espinhos estudados sejam atribuídos a uma nova espécie de Sphenacanthidae.

Palavras chave: Permiano, Guadalupiano, bacia do Paraná, Sphenacanthidae, espinhos de nadadeira.

\section{INTRODUCTION}

The chondrichthyans from the Paleozoic are mainly known from teeth, scales, cephalic spines and finspines, as complete specimens are rare. In the Permian of Brazil, finspines occur in the Parnaíba Basin, Pedra de Fogo Formation (Richter, 1985, 2001, 2008; Alves et al., 2008, 2009a,b; Alves, 2010) and in the Paraná Basin in the Rio Bonito (Silva-Santos, 1947), Tatuí/ Irati (Chahud et al., 2010), Estrada Nova (Würdig-Maciel, 1975) and Rio do Rasto formations (Sedor et al., 2009; Pauliv et al., 2010a,b).
Gordon Jr. (1947) divided the Rio do Rasto Formation into two members: the Serrinha (lower) and the Morro Pelado (upper). This formation is considered to be of Permian age, spanning from the Wordian to Wuchiapingian (Holz et al., 2010).

The Serrinha Member has some different interpretations; however, most of them propose a shallow lacustrine environment (e.g. Mendes, 1967). To Schneider et al. (1974) this unit is the result of progradational advances of clastics from coastal plain over tidal plains deposits, which characterize the transition from shallow water bodies of the Terezina Formation to continental deposits of the Morro 
Pelado Member. According to Lavina (1991), the sedimentary rocks of the Serrinha Member were deposited in lacustrine and deltaic environments, with a predominance of large lakes influenced by storm waves. Recently, Holz et al. (2010) considered the Serrinha Member as deposited in shallow lakes, sometimes influenced by storm waves and fluvial incursions.

The sedimentary rocks of Morro Pelado Member were deposited in smaller lakes, alluvial plains, fluvial meandering streams and delta systems with interdistributary bays, as well as in small temporary water bodies (Lavina, 1991; Holz et al., 2010). The rocks of the Morro Pelado Member were covered by aeolian sandstones, as indicated by the presence of dunes in the Piramboia Formation. The faunistic and floristic record in the Rio do Rasto Formation supports this paleoenvironmental interpretation.

The flora is diversified and the most common genera are Schizoneura Schimpmer \& Mougeol, 1844, Paracalamites Zalessky, 1927, Glossopteris Brongniart, 1828 and Pecopteris Sternberg, 1825; there is also a palinologic record (e.g. Mendes, 1967; Rohn et al., 1997; Rohn \& Rösler, 2000; Neregato et al., 2008). The invertebrates are mainly represented by bivalve mollusks, ostracodes and conchostracan crustaceans (e.g. Mendes, 1954; Ferreira-Oliveira \& Rohn, 2008; 2009). The presence of conchostracans suggests freshwater conditions for the depositional environment for the whole of the Rio do Rasto Formation (Holz et $a l ., 2010)$. The vertebrates are also diversified and represented by fishes, amphibians, reptiles and ichnofossils (Dias, 2012).

The occurrence of two Sphenacanthidae from the Serrinha Member of Rio do Rasto Formation (Paraná State) reported by Pauliv et al. (2010a,b), which are detailed in this paper with the erecting of a new species for this unit. Knowledge about the chondrichthyan diversity may contribute to the comprehension of some paleoenvironmental and paleobiogeographical aspects.

\section{MATERIAL AND METHODS}

The studied material comprises two finspines collected from an outcrop of the Serrinha Member of Rio do Rasto Formation in the northeastern region of Paraná State, Jacarezinho Municipality, near km 20, west margin of road BR-
153 , coordinates $23^{\circ} 10^{\prime} 08.40^{\prime \prime} \mathrm{S}, 49^{\circ} 57^{\prime} 49.48^{\prime \prime} \mathrm{W}$ (Figure 1).

The material is housed in the paleontological collections of the Museu de Ciências Naturais, Setor de Ciências Biológicas, Universidade Federal do Paraná under the numbers MCN.P.440 and MCN.P.703. The first specimen was collected in association with some isolated actinopterygian scales and with a xenacanthiform shark tooth (Pauliv et al., 2010b).

The specimens were prepared by mechanical techniques with steel tips, under a stereomicroscope following the usual methodology for small vertebrate fossils (e.g. Camp \& Hanna, 1937; Santos, 1985; Leiggi \& May, 1994). The samples were impregnated with polystyrene dissolved in xylol to increase the fossil resistance, and were photographed with a Sony DSC H-7 8.1 megapixels digital camera and with an Olympus SZX9 stereomicroscope at the Laboratório de Microtécnica of the Universidade Positivo. Finally, the taxonomic determination of the specimens was mainly based on the revised diagnosis proposed by Maisey $(1981,1982)$ for some Paleozoic genera. The material used for comparison were: Ctenacanthus gondwanus Silva-Santos, 1947 (DGM 73-P, holotype of the species) and C. maranhensis Silva-Santos, 1946 (DGM 470-P, a series of fragments of finspines). Institutional abbreviations: DGM, Divisão de Mineralogia e Geologia; DNPM, Departamento Nacional de Produção Mineral; MCN, Museu de Ciências Naturais; UFPR, Universidade Federal do Paraná.

\section{SYSTEMATIC PALEONTOLOGY}

Class CHONDRICHTHYES Huxley, 1880

Subclass ELASMOBRANCHII Bonaparte, 1838

Infraclass EUSELACHII Hay, 1902 (sensu Ginter et al., 2010)

Family SPHENACANTHIDAE Maisey, 1982

Sphenacanthus Agassiz, 1837 (sensu Maisey, 1982)

Type species. Sphenacanthus serrulatus Agassiz, 1837.

Sphenacanthus riorastoensis sp. nov.

(Figures 2-3)

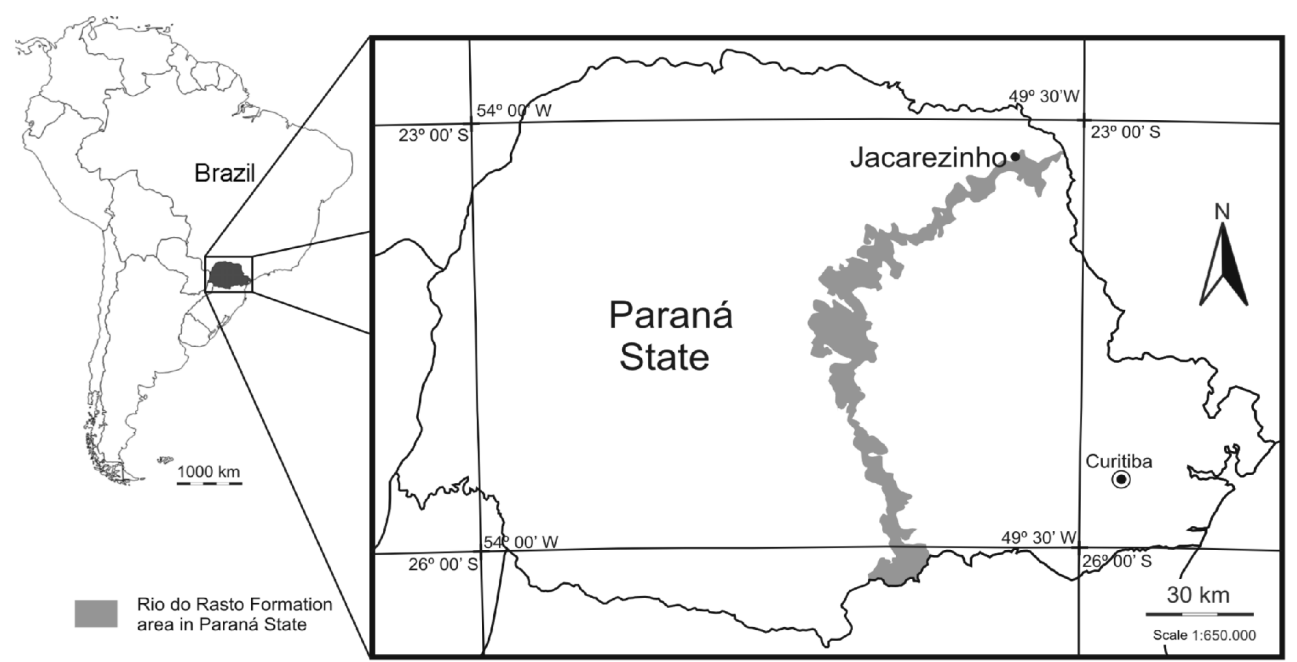

Figure 1. Distribution of the Rio do Rasto Formation in the Paraná State with the location of the collecting site in the Municipality of Jacarezinho (modified from Mineropar, 2006). 
Etymology. Referring to the Rio do Rasto Formation. Holotype. MCN.P.440, one incomplete finspine lacking part of the proximal and most distal extremities (Figure 2).

Paratype. MCN.P.703 corresponds to the median distal portion of a finspine with both extremities missing (Figure 3). Type locality and horizon. Serrinha Member of the Rio do Rasto Formation (Wordian to Wuchiapingian following Holz et al. 2010), Passa Dois Group, Municipality of Jacarezinho, northeastern region of Paraná State, Southeastern Brazil.

Diagnosis. Chondrichthyan only known from finspines that present a gradually tapered distal portion; convex lateral face forming a narrow edge anteriorly with a single and smooth longitudinal rib; isosceles triangle-shaped in transverse section; posterior face with a deep concavity proximally and slightly concave distally, limited by posterolateral ribs with tubercles; twice as deep as broad cross-section; presence of prominent parallel ribs, which are separated by intercostal grooves as wide as or slightly smaller than the ribs' width; ribs branching irregularly in the posterior portion of the finspine; ribs beaded with rows of rounded drop-like tubercles, the diameters of which are bigger than the ribs' width; larger tubercles in the proximal portion of the finspine and the spacing of the tubercles is smaller than the tubercles' size.

Description. The maximum dimensions of specimen MCN.P.440 are $104 \mathrm{~mm}$ along its proximal-distal axis and $23 \mathrm{~mm}$ anteroposteriorly. Specimen MCN.P.703 is $16 \mathrm{~mm}$ in length along its proximal-distal axis while the anteroposterior axis is $9 \mathrm{~mm}$ proximally and $5 \mathrm{~mm}$ distally. The finspines of Sphenacanthus riorastoensis sp. nov. are laterally compressed, almost twice as deep as broad in transverse section, and present a convex lateral surface forming a narrow anterior edge that gradually tapers distally. In the proximal third of the finspine there is an oblique line slightly sigmoid in shape, which limits the intramuscular portion from the external body portion of the spine (Figure 2A). This proximal portion has only fine striations, while the external portion shows ribs and tubercles. In specimen MCN.P.440, this external portion is 93 $\mathrm{mm}$ in length anteriorly and $75 \mathrm{~mm}$ posteriorly (Figure 2A). The entire external portion of the finspines present parallel ribs (costae), and these ribs are beaded with closely spaced rows of rounded drop-like tubercles. The distance between the tubercles is equal to the tubercle size or, rarely, shorter, as seen on the proximal portion (Figures 2A-C), and slightly shorter than the tubercle size on their distal portions (Figures 3A-B). Among these ribs there are furrows (intercostal grooves), which are smooth and as wide as the ribs' width or slightly smaller. These ribs may branch on the proximal portion as seen in MCN.P.440 (Figure 2C) and also on the distal third as seen in MCN.P.703 (Figures 3A,B). Moreover, the tubercles of the proximal region are larger, presenting a gradual reduction in diameter along the spine and becoming more numerous distally. The anterior edge has a single narrow and smooth longitudinal rib, with only one visible tubercle on specimen MCN.P.703 (Figure 3C). In transversal cross-section the specimen shows a sub-circular median cavity (pulpar cavity) surrounded by a spongy region (Figures 3D,E), similar to that described by Maisey (1982) as trabecular dentine. The proximal portion of the finspine presents on its posterior face a deep concavity forming a posterior furrow with rounded edges, as seen in basal view (Figure 2B). On its median region, this posterior furrow becomes shallow and probably the lateral edges join forming the pulpar cavity (Figure 3E). From the medial region to the apical portion the posterior face presents a slight concavity formed by posterolateral ribs with tubercles, one on each edge (Figures 3D-F). A pronounced posterior median ridge or convexity is absent, but shallow and short discontinuous furrows are present. Thus, from the medial to the apical region, the finspine has a subtriangular cross-section (Figures 3D-E).

\section{COMPARISON AND DISCUSSION}

For many years due to the similarity between the finspines of Sphenacanthus and Ctenacanthus Agassiz, 1837 these genera were considered as synonyms (Maisey, 1982) and Sphenacanthus placed in the Ctenacanthiformes (e.g. Zangerl, 1981). However, the discovery of more complete specimens of Sphenacanthus with association of finspines and teeth (e.g. Soler-Gijón, 1997; Dick, 1998; Krätschmer \& Forst, 2005), allowed changes in the systematic determination of the family Sphenacanthidae. Soler-Gijón (1997) and Ginter et al. (2010) reallocated this family to incertae sedis in the Cohort Euselachii based on the similarity between the teeth of sphenacanthids and the teeth of the basal hybodontid Trystichius Portlock, 1843 , and also demonstrated that they deeply diverge from the Ctenacanthiformes in tooth morphology. Thus, in modern systematics (based on tooth morphology) the Sphenacanthus belongs in the Euselachii while the Ctenacanthiformes are in the superorder Cladodontomorphi (Ginter et al., 2010).

Here is presented a comparison between the studied finspines (MCN.P.440 and MCN.P.703) based on the diagnosis revised by Maisey $(1981,1982)$ for the following Paleozoic genera: Ctenacanthus; Amelacanthus Maisey, 1982; Bythiacanthus St. John \& Worthen, 1875; Eunemacanthus St. John \& Worthen; Wodnika Müster, 1843 and Sphenacanthus.

Ctenacanthus was first described by Agassiz (1837) based only on isolated finspines. Agassiz himself and other authors added many species based on finspines without a clear diagnosis, making the systematics of the group confuse (Maisey 1981, 1982). Ctenacanthus was restricted by Maisey (1981) to finspines with a similar ornamental pattern to that present in the type species C. major Agassiz, 1837. Comparing specimens MCN.P.440 and MCN.P.703 with the revised diagnosis of Maisey (1981), these are distinguished from Ctenacanthus by not having: (i) numerous closely spaced fine longitudinal ribs; (ii) closely pectinated ribs with minute transverse tuberculations often vertically striated and projected laterally from the raised ribs; and (iii) tubercles of adjacent ribs almost touching and sometimes interlocking like teeth on a zipper.

According to Maisey (1982), Amelacanthus presents the following features: (i) posteriorly divergent sides but almost flat, giving a subtriangular outline in cross-section; (ii) ornament of broad smooth ribs, which are heavily enameled and usually display growth lines; and (iii) ribs with narrow intercostal grooves. These features are not present in MCN.P.440 and MCN.P.703. 
Bythiacanthus (sensu Maisey, 1982) presents: (i) robust finspines with a rhomboidal outline in lateral view; and (ii) longitudinal rows of rounded and striated tubercles, usually less than their own diameter apart. These features are absent in the Rio do Rasto Formation specimens. Moreover, Bythiacanthus presents a strongly concave posterior face, forming a deep posterior furrow, a distinct condition to that found in MCN.P.440, which is only slightly concave proximally, and in MCN.P.703, in which the posterior face is almost flat.
The finspines described here could not belong to Eunemacanthus (sensu Maisey, 1982), since they are not so laterally compressed and do not present a broad anterior margin with a wide enameled rib; thick irregular enameled lateral ribs interrupted by transverse ridges, or intercostal areas occupied by irregularly dispersed tubercles or short lengths of ribbing.

As Wodnika finspines present smooth ribs (Maisey 1982), none of the spines described here can be attributed to this genus.

According to the revised diagnosis of Sphenacanthus by

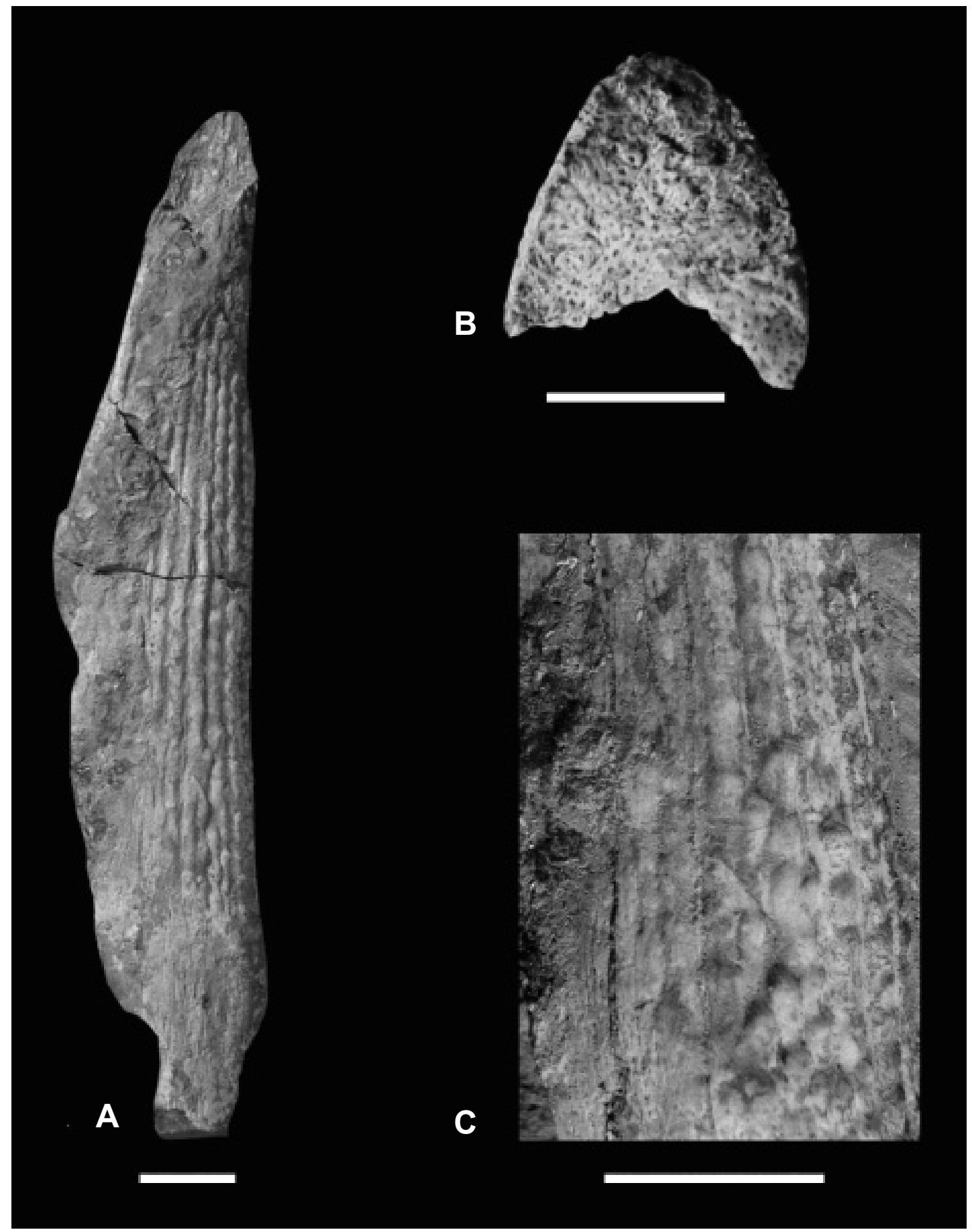

Figure 2. Sphenacanthus riorastoensis sp. nov., finspine, specimen MCN.P.440 (holotype). A, the finspine in lateral view; B, transverse section of the proximal portion; $\mathbf{C}$, detail of the branching ribs and the tubercles of the proximal portion of the spine. Scale bars: $A-C=10 \mathrm{~mm} ; B=5 \mathrm{~mm}$. 


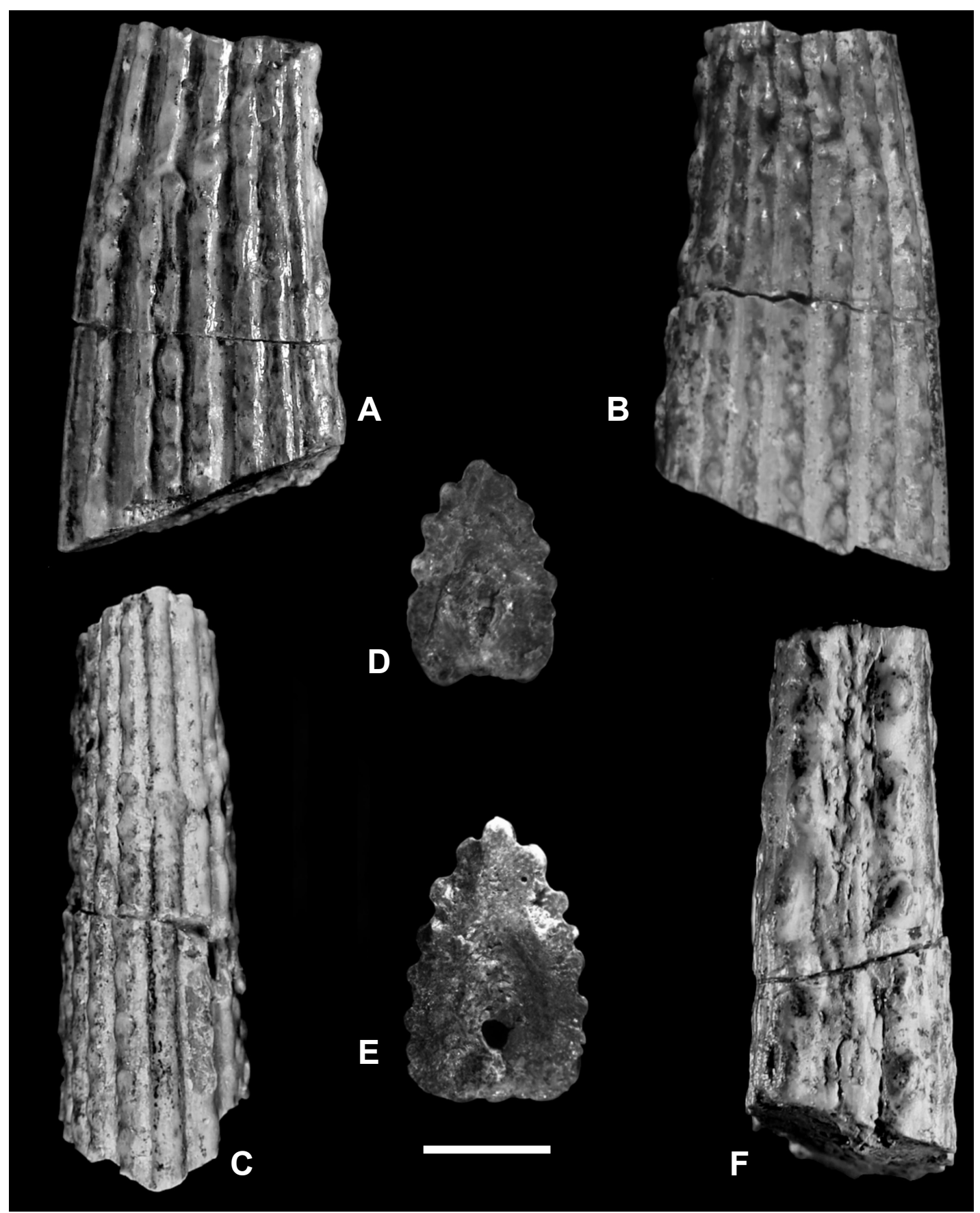

Figure 3. Sphenacanthus riorastoensis sp. nov., finspine, specimen MCN.P. 703. A, left lateral view; B, right lateral view; C, anterior view; D, distal transverse cross-section; E, proximal transverse cross-section; $\mathbf{F}$, posterior view. Scale bar $=5 \mathrm{~mm}$.

Maisey (1981, 1982), some characteristics observed in the finspines MCN.P.440 and MCN.P.703 are compatible with this genus. They share with Sphenacanthus the following features: (i) finspines that gradually taper and are slightly curved posteriorly, often with a straight posterior profile; (ii) an acutely rounded anterior face and slightly convex lateral faces; (iii) the posterior face concave proximally as seen in MCN.P.440 and almost flat to slightly concave distally lacking a pronounced median ridge as seen in MCN.P.703; (iv) a cross-section approximately twice as deep as broad as seen in MCN.P.703; (v) the presence of prominent raised ribs of variable distance apart; (vi) intercostal grooves generally as wide as or wider than the ribs (except in MCN.P.440 and posterior ribs of MCN.P.703, which present grooves slightly smaller than the width of the ribs); (vii) ribs that are nodose and discontinuous branching irregularly, with new ones sometimes appearing by intercalation or often by addition to the marginal ribs; (viii) nodose ribs that are never closely pectinated, but beaded with small and well-spaced tuberculations that may be thinly enameled; and (ix) posterolateral margins presenting a row of low tubercles directed posteriorly.

However, the feature "intercostal grooves generally as 
wide as or wider than ribs" mentioned in Maisey's (1982) diagnosis is ambiguous in the studied specimens. MCN.P.440 presents intercostal grooves smaller than the width of the ribs; while in MCN.P.703, the anterior intercostal grooves are as wide as the ribs' width, but narrower in the posterior ones. Thus, it seems that this feature is not obligatory in the genus, and its absence does not endanger the identification of the specimens as Sphenacanthus.

The Sphenacanthus genus has been known for almost two centuries when it was first described by Agassiz (1837) based on fossils from the Carboniferous of Scotland. The relationships between the sphenacanthids have been controversial until now, with less than ten species formally described. Below will be presented a short comparison between some Laurasian species followed by comparison with some Brazilian species that closely resemble Sphenacanthus riorastoensis sp. nov.

The description of Sphenacanthus serrulatus Agassiz, 1837 was based on a single badly preserved finspine, and many years later this genus were redescribed by Dick (1998) based on an almost complete specimen from the Viséan Upper Oil Shale Group of Scotland. S. riorastoensis sp. nov. differs from this species by the presence in $S$. serrulatus of fine crenulated ribs practically without tubercles, and the number of ribs on the lateral surfaces are proportionally greater.

Sphenacanthus carbonarius Giebel, 1848 is another Laurasian sphenacanthid proposed for the Puertollano Basin, Late Carboniferous of Spain (Soler-Gijón, 1997). Recently these species were also reported from the Top Breitenbach Formation (Stefan C) of the Saar-Nahe Basin by Krätschmer $\&$ Forst (2005). The finspines of this species present almost smooth ribs, sometimes with a few tubercles, and some of these tubercles occur in the intercostal grooves, which does not occur in $S$. riorastoensis sp. nov.

The occurrences of another Brazilian sphenacanthid and ctenacanthid finspines have been reported (e.g. Silva-Santos, 1946, 1947; Würdig-Maciel, 1975; Richter, 2001, 2008; Alves et al., 2008, 2009a,b; Alves, 2010; Chahud et al., 2010) and comparisons with these are presented below.

The finspines from the Pedra de Fogo Formation (Lower Permian of Maranhão State) described by Silva-Santos (1946) were attributed to Ctenacanthus maranhensis. This taxon was reevaluated by Maisey (1984), who suggested that its shape in transverse section and ornamentation pattern was not referable to Ctenacanthus, and may be closer to Sphenacanthus or to Wodnika. However, the emended diagnosis of Wodnika proposed by Maisey (1982) affirms that this genus exhibits smooth ribs, which is incompatible with $C$. maranhensis, so is here considered Sphenacanthus maranhensis. The finspines of S. maranhensis are very similar to specimen MCN.P.703 in general shape, in its posterior face morphology and in its tubercle distribution pattern, but $S$. maranhensis presents a higher number of ribs, smaller rib width and smaller tubercle diameter than specimen MCN.P.703.

For the same formation, Richter $(2001,2008)$ mentioned the occurrence of some ctenacanthiform finspines in the Pedra de Fogo Formation, Guaraí Municipality, Tocantins State. According to Richter (2008) these finspines are identical to the Lower Permian Ctenacanthus amblyxiphias Cope, 1891, of Kansas (USA), diverging on the ornamentation pattern from $S$. maranhensis and consequently from $S$. riorastoensis $\mathrm{sp}$. nov. The finspines studied by Richter (2008) were collected associated with a cladodont tooth attributed to Glikmanius occidentalis (Leidy, 1859) (= Cladodus occidentalis Leidy, 1859) previously known from the Pennsylvanian-Lower Permian of the USA, Late Carboniferous of England and Carboniferous of Russia, which suggests a possible synonym between these two species. New finspine occurrences from the same locality were mentioned by Alves et al. $(2008,2009 a, b)$ and Alves (2010).

Another Brazilian shark finspine was collected in the Taió sandstone (Santa Catarina State), currently positioned in Rio Bonito Formation of Early Permian age, and described by Silva-Santos (1947) as Ctenacanthus gondwanus SilvaSantos, 1947. This species was also reevaluated by Maisey (1984) and may be referable to Sphenacanthus based on its ornamentation pattern. So is here adopted as S. gondwanus based on Maisey (1984). Specimen MCN.P.440 resembles $S$. gondwanus in some features such as: (i) equivalent size; (ii) intercostal grooves smaller than ribs; (iii) proximal tubercles more developed; and (iv) presence of branching ribs. SilvaSantos (1947) believed that this rib bifurcation could be an anomaly that would be not recorded in all sharks of this species. However, this feature was considered by Maisey (1982) to be diagnostic for the group and not an anomaly. Nevertheless, unlike in S. gondwanus, the finspines described here do not exhibit tubercles separated by distances equal to three times their diameter and ribs that becomes smooth distally. In both specimens (MCN.P.440 and MCN.P.703) the ribs have a row of tubercles throughout their extension.

Chahud et al. (2010) described a ctenacanthiform finspine collected in the transition between the Tatuí and Irati formations, Paraná Basin (São Paulo State), placing it in the Sphenacanthidae and proposing the species Sphenacanthus sanpauloensis Chahud, Fairchild \& Petri 2010. This species shares some similarities with MCN.P.440 and MCN.P.703, such as: branching ribs, boundary between ornamented faces and intramuscular tissue having a sigmoid shape and lateral faces separated by only one anterior rib. But it differs from $S$. riorastoensis sp. nov. in that the ornamentation pattern of this species presents tubercles separated from each other by a distance twice that of their diameter, tubercles generally cylindrical and ribs separated by intercostal grooves equivalent to or slightly greater in width than half the width of the rib.

Würdig-Maciel (1975) described a shark finspine collected from an outcrop of the Estrada Nova Formation (actually this outcrop probably belongs to Terezina Formation, which is Early to Middle Permian sensu Holz et al., 2010). Despite the poor preservation condition of this specimen, this finspine differs from MCN.P.440 and MCN.P.703 by having six large and smooth ribs that disappear near the posterior edge. This material was identified as Ctenacanthus by Würdig-Maciel (1975), but smooth ribs are incongruent with the revised diagnosis of the genus (Maisey, 1981) so, this specimen should not belong to Ctenacanthus. 


\section{Paleoenvironmental remarks}

The genus Sphenacanthus was based on a single finspine collected in a freshwater limestone by Agassiz (1837). For Baird (1978), it is clear that many Paleozoic and Mesozoic sharks lived in freshwater environments. According to Zangerl (1981), ctenacanths (including Sphenacanthus) have been recovered from marine, paralic and freshwater deposits; consequently, these sharks can be considered as euryhaline (Silva-Santos, 1994). Dick (1998) suggested that Sphenacanthus was an inhabitant of fresh or brackish waters lagoons. Soler-Gijón (1997) mentioned that $S$. carbonarius of the Puertollano Basin was recovered from sediments deposited under a marine-influenced environment, based on the depositional features and the occurrence of acritarchs. However, this author mentioned the co-occurrence of valves of chonchostracans, smooth ostracodes and insect remains, which are strong evidence of fresh or brackish water conditions. In the case of the Puertollano Basin, the complexity of the paleoenvironment precludes a precise conclusion for the habitat of $S$. carbonarius.

The Rio do Rasto Formation has been interpreted as being deposited in a freshwater environment; for example, Ragonha (1989) based on the occurrence of dipnoan fishes and Holz et al. (2010) based on the record of conchostracans, megaplants and ferns. This allied with the whole paleontological record, as already mentioned, indicates freshwater and continental conditions for the Rio do Rasto Formation. So Sphenacanthus riorastoensis sp. nov. of the Serrinha Member presented here, the xenacanthid of the same horizon mentioned by Pauliv et al. (2010) and the hybodontid teeth studied by Laurini et al. $(2009,2010)$ from the Morro Pelado Member represent new freshwater records for each of these sharks.

\section{CONCLUSIONS}

The finspines described here are identified as belonging to the genus Sphenacanthus Agassiz (1837) and ascribed to a new species, $S$. riorastoensis sp. nov. This species closely resembles the finspines of S. maranhensis, S. gondwanus and S. sanpauloensis, all also described from Brazilian territory, which indicates endemism of these sharks in the Brazilian basins during the Permian age as already mentioned by Chahud et al. (2010).

The specimen MCN.P.440 described here as the holotype of Sphenacanthus riorastoensis $\mathrm{sp}$. nov. was collected associated with another shark tooth preliminarily attributed to the Xenacanthiformes. This record suggests that these two fossil sharks lived together in the shallow freshwater environments of the Serrinha Member of the Rio do Rasto Formation.

\section{ACKNOWLEDGMENTS}

The authors thank the Museu de Ciências Naturais in memoriam of professor E.F. da Silva Junior for providing most of the necessary infrastructure and equipment for the execution of this work; the Universidade Positivo for providing the "Laboratório de Microtécnica" to take photos of the specimens; M. Ginter and A. Ivanov for reviewing the manuscript; R.C. Silva and M.B.L. Santos for their comments on the manuscript during its preparation; E. Eltink for help finding some references; the Pro-Reitoria de Extensão e Cultura of UFPR and the CNPq for providing a scholarship to V.E.P. during the preparation of this paper.

\section{REFERENCES}

Agassiz, L. 1837. Recherches sur les Poisons Fossiles. Neuchatel, 5 vols., 1833-1844. 1420 p.

Alves, Y.M. 2010. Los vertebrados fóssiles del Paleozoico y Mesozoico del Estado de Tocantins (Brasil): a preliminar síntesis. Caminhos de Geografia (UFU), 11:224-236.

Alves, Y.M.; Matos da Silva W.; Marinho T.S. \& Candeiro C.R.A. 2009a. Espinhos e dentes isolados de tubarões do Permiano do Estado do Tocantins. Ameghiniana, 46:7R.

Alves, Y.M.; Souza F.E.F; Marinho T.S. \& Candeiro C.R.A. 2009b. La diversidad de la paleoictiofauna de la Formacíon Pedra de Fogo (Pérmico superior) de la Cuenca Parnaíba en Brasil. Ameghiniana, 46:7R.

Alves, Y.M.; Tavares, L.F.S.; Matos da Silva, W. \& Candeiro, C.R.A. 2008. Um Ctenacanthidae (Chondrichthyes, Elasmobranchii) da Bacia do Parnaíba, Estado do Tocantins, Brasil. In: CONGRESO LATINOAMERICANO DE PALEONTOLOGÍA DE VERTEBRADOS, 3, 2008. Libro de Resúmenes, Neuquén, p. 10.

Baird, D. 1978. Studies on Carboniferous freshwater fishes. American Museum Novitates, 641:1-22.

Camp, C.L. \& Hanna, D.G. 1937. Methods in Paleontology. Berkeley, University California Press, 153 p.

Chahud, A.; Fairchild, T.R. \& Petri, S. 2010. Chondrichthyans from the base of the Irati Formation (Early Permian, Paraná Basin), São Paulo, Brazil. Gondwana Research, 18:528-537. doi:10.1016/j.gr.2010.01.006

Dias, E.V. 2012. A new deep-bodied fossil fish (Actinopterygii) from the Rio do Rasto Formation, Paraná, Basin, Brazil. Zootaxa, 3192:1-23.

Dick, J.R.F. 1998. Sphenacanthus, a Palaeozoic freshwater shark. Zoological Journal of Linnean Society, 122:9-2. doi:10.1111/j.1096-3642.1998.tb02523.x

Ferreira-Oliveira, L.G. \& Rohn, R. 2008. Conchostráceos com linhas de crescimento recurvadas junto à margem dorsal (famílias Palaeolimnadiopseidae e Perilimnadiidae) da Formação Rio do Rasto, Permiano Superior, bacia do Paraná, Brasil. Geologia USP Série Cientifica, 8:41-52.

Ferreira-Oliveira, L.G. \& Rohn, R. 2009. Leaiid conchostracans from the uppermost Permian strata of the Paraná Basin, Brazil: Chronostratigraphic and paleobiogeographic implications. Journal of South American Earth Sciences, 29:371-380.

Ginter, M.; Hampe, O. \& Duffin, C. 2010. Chondrichthyes Paleozoic Elasmobranchii: Teeth. In: H.-P. Schultze (ed.) Handbook of Paleoichthyology, 3D. Verlag Dr. Friedrich Pfeil, p 1-168.

Gordon JR O. 1947. Classificação das formações gonduânicas do Paraná, Santa Catarina e Rio Grande do Sul. Notas Preliminares e Estudos. Rio de Janeiro, Departamento Nacional de Produção Mineral, Divisão de Geologia e Mineralogia, 20 p. (Boletim 38).

Holz, M.; França A.B.; Souza, P.A.; Iannuzzi, R. \& Rohn, R. 2010. A stratigraphic chart of the Late Carboniferous/Permian succession of the eastern border of the Paraná Basin, Brazil, South America. Journal of South American Earth Sciences, 29:381-399. doi:10.1016/j.jsames.2009.04.004 
Krätschmer, K. \& Forst, M.H. 2005. Ein Neufund von assoziierten skelettelementen von Sphenacanthus cf. carbonarius (Giebel 1848) aus dem Top Oberkarbon (Breitenbach-Fm., Stefan C) des Saar-Nahe Beckens (SW-Deutschland) mit Anmerkungen zur Paläoökologie der Vertebraten-Lokalitäten von Altenkirchen. Geowissenschaftliche Beiträge zum Saarpfälzischen Rotliegenden, 3:29-37.

Laurini, C.R.; Langer, M.C. \& Richter, M. 2009. Chondrichthyan teeth from the Rio do Rasto Formation, Permian of Brasil. Journal of Vertebrate Paleontology, 29:133A.

Laurini, C.R.; Langer M.C. \& Richter M. 2010. Morfologia e ultraestrutura de dentes associados a um euseláquio da Formação Rio do Rasto (Permiano Superior, Bacia do Paraná), estado do Paraná. Paleontologia em Destaque, p. 21 (Boletim Edição Especial da SBP).

Lavina, E.L. 1991. Geologia sedimentar e paleogeográfica do Neopermiano e Eotriássico (Intervalo Kazaniano-Scithiano) da bacia do Paraná. Programa de Pós-Graduação em Geociências, Universidade Federal do Rio Grande do Sul, Tese de Doutorado, $333 \mathrm{p}$.

Leiggi, P. \& May, P. 1994. Vertebrate Paleontological Techniques. Cambridge, Cambridge University Press, 344 p.

Maisey, J.G. 1981. Studies on the Paleozoic Selachian genus Ctenacanthus Agassiz No. 1. Historical review and revised diagnosis of Ctenacanthus, with a list of referred taxa. American Museum Novitates, 2718:1-21.

Maisey, J.G. 1982. Studies on the Paleozoic Selachian genus Ctenacanthus Agassiz. No. 2. Bythiacanthus St. John and Worther, Amelacanthus, new genus, Eunemacanthus, St. John and Worthen, Sphenacanthus Agassiz, and Wodnika Münster. American Museum Novitates, 2722:1-24.

Maisey, J.G. 1984. Studies on the Paleozoic Selachian genus Ctenacanthus Agassiz. N. 3. Nominal species referred to Ctenacanthus. American Museum Novitates, 2774:1-20.

Mendes, J.C. 1954. Conchostráceos permianos do sul do Brasil. In: F.W. Lange (ed.) Paleontologia do Paraná, Museu Paranaense, p. 153-164.

Mendes, J.C. 1967. The Passa Dois Group (The Brazilian Portion of the Paraná Basin). In: J.J. Bigarella; R.D. Becker \& J.D. Pinto (eds.) Problems in Brazilian Gondwana Geology, Papelaria Max Roesner Ltda, 344 p.

Mineropar. 2006. Mapa geológico do Estado do Paraná. Available at: http://www.mineropar. pr.gov.br/arquivos/Files/2_Geral/ Geologia/PDF_Mapa_Geo_650000/Mapa_Geologico_ PR_650000_2006.pdf; accessed on 05/01/2012.

Neregato, R.; Souza, P.A. \& Rohn, R. 2008. Registros palinológicos Inéditos nas Formações Teresina e Rio do Rasto (Permiano, Grupo Passa Dois, Bacia do Paraná) Implicações Biocronoestratigráficas e Paleoambientais. Revista Pesquisas em Geociências, 35:9-21.

Pauliv, V.E.; Dias, E.V. \& Sedor, F.A. 2010a. Espinhos de Sphenacanthus (Chondrichthyes) da Formação Rio do Rasto no Estado do Paraná. Paleontologia em Destaque, p. 64 (Boletim da SBP 63).

Pauliv, V.E.; Dias, E.V. \& Sedor, F.A. 2010b. Ocorrência de Xenacanthida (Chondrichthyes: Elasmobranchii) para o Membro Serrinha da Formação Rio do Rasto (Bacia do Paraná) no Estado do Paraná. Paleontologia em Destaque, p. 22. (Boletim Edição Especial da SBP).
Ragonha, E.W. 1989. Placas dentárias de Dipnoi no Grupo PassaDois (P-Tr) da Bacia do Paraná. Apreciações ambientais, climáticas, cronológicas e estratigráficas. In: CONGRESSO BRASILEIRO DE PALEONTOLOGIA, 11, 1989. Anais, Curitiba, p. 195-206.

Richter, M. 1985. Situação da pesquisa paleoictiológica no Paleozoico Brasileiro. Coletânea de Trabalhos Paleontológicos, p. 105-110 (Série Geologia 27 Seção de Paleontologia e Estratigrafia 2).

Richter, M. 2001. Fishes from the Permocarboniferous of the Parnaíba Basin in the State of Tocantins, North Brazil, and their palaeoenvironment. Revista Brasileira de Paleontologia, 2:142.

Richter, M. 2008. Ctenacanthid shark remains (Chondrichthyes) from the Lower Permian Pedra do Fogo Formation, State of Tocantins, Brazil. Journal of Vertebrate Paleontology, 28:131A.

Rohn, R. \& Rösler, O. 2000. Middle to Upper Permian phytostratigraphy of the eastern Paraná Basin. Revista Geociências Guarulhos, Geociências, 5:69-73.

Rohn, R.; Rösler, O.; Pennatti, J-R.R.; Davies, H-P.K. \& Cavalheiro, M.C.T. 1997. Ocorrências de macrofitofósseis nas formações Terezina e Rio do Rasto (Permiano Superior da Bacia do Paraná) na região de Cândido Abreu-Reserva, Estado do Paraná, Brasil. Revista da Universidade de Guarulhos, Geociências, 2:69-75.

Santos, O.S. 1985. Técnicas de Preparação de Fósseis. Brasília, DNPM, $127 \mathrm{p}$.

Schneider, R.L.; Mühlmann, E.; Tommasi E.; Medeiros, L.A.; Daemon, A. \& Nogueira, A.A. 1974. Revisão Estratigráfica da Bacia do Paraná. In: CONGRESSO BRASILEIRO DE GEOLOGIA, 28, 1974. Anais, Porto Alegre, p. 41-65.

Sedor, F.A.; Pauliv, V.E. \& Dias, E.V. 2009. Icthyodorulitos (Chondrichthyes, Ctenacanthiformes) nos membros Morro Pelado e Serrinha da Formação Rio do Rasto (Permiano Superior) da bacia do Paraná no Estado do Paraná. Paleontologia em Destaque, p. 19 (Boletim da SBP 62).

Silva-Santos, R. 1946. Duas novas formas de Elasmobrânquios do Paleozóico do Meio Norte, Brasil. Anais da Academia Brasileira de Ciências, 18:281-287.

Silva-Santos, R. 1947. Um Ctenacanthus do Gondwana brasileiro. Anais da Academia Brasileira de Ciências, 19:247-253.

Silva-Santos, R. 1994. Paleoictiofauna da Formação Pedra de Fogo. Bacia do Parnaíba, NE do Brasil: II Eugeneodontida Agassizodontidae. Anais da Academia Brasileira de Ciências, 66:413-424.

Soler-Gijón, R. 1997. Euselachian sharks from the Late Carboniferous of the Puertollano Basin, Spain: bioestratigraphic and palaeoenvironmental implications. Modern Geology, 21:137-169.

Würdig-Maciel, N.L. 1975. Ichthyodontes e ichthyodorulitos (Pisces) da Formação Estrada Nova e sua aplicação na estratigrafia do Grupo Passa-Dois. Pesquisas, 5:7-85.

Zangerl, R. 1981. Chondrichthyes I - Paleozoic Elasmobranchii. In: H.-P. Schultze (ed.) Handbook of Paleoichthyology, Gustav Fischer Verlag, 115 p.

Received in April, 2012; accepted in November, 2012. 